\title{
COMPARATIVE STUDY OF EXPERIMENTAL AND ANALYTICAL RESULTS OF FRP STRENGTHENED BEAMS IN FLEXURE
}

\author{
Shaishav R. Viradiya ${ }^{1}$, Tarak P. Vora ${ }^{2}$ \\ ${ }^{1}$ PG Student, Civil Engineering Department, Marwadi Education Foundation, Gujarat, India \\ ${ }^{2}$ Associate Professor\&Head, Civil Engineering Department, Marwadi Education Foundation, Gujarat, India
}

\begin{abstract}
This paper presents the nonlinear Finite Element Analysis (FEA) that has been carried out to simulate the behaviour of failure modes of Reinforced Concrete (RC) beams strengthened in flexure by Fibre Reinforced Polymer (FRP) laminates. Two beams were modeled in FEM software using ANSYS. In those two beams, one beam is control beam without FRP and other beam is Glass Fibre Reinforced Polymer (GFRP) strengthened beams. From the analyses the load deflection relationships, crack pattern, first crack load and Ultimate load was obtained and compared with the experimental results available in Literature. The load deflection plots obtained from numerical studies show good agreement with the experimental plots. There was a difference in behaviour between the RC beams strengthened with and without GFRP layers. Therefore, modeling of experimental beams can be adoptable in ANSYS. Validation of experimental results can also be done using ANSYS.
\end{abstract}

Keywords: Fibre Reinforced Polymer (FRP); finite element Analysis; ANSYS; GFRP; modeling

\section{INTRODUCTION}

The application of fibre reinforced polymers as external reinforcement has received much attention from structural engineering. FRP laminates have gained popularity as external reinforcement for the strengthening or rehabilitation of reinforced concrete structures. Externally bonded FRP laminates and fabrics can be used to increase the flexural strength of reinforced concrete beams. Flexural strengthening of beams, however, is likely to be more problematic when they are cast monolithically with slabs. Bonding FRP reinforcement to the tension face of a concrete flexural member with fibers oriented along the length of the member will provide an increase in flexural strength. FRP composites applied to the reinforced concrete members provide efficiency, reliability and cost effectiveness in rehabilitation. Experimental based testing has been widely used as a means to analyze individual elements and the effects of concrete strength under loading. While this is a method that produces real life response, it is extremely time consuming and the use of materials can be quite costly. The use of finite element analysis to study these components has also been used. Analytical modeling has been done for reinforced concrete beams externally reinforced with FRP laminates using FEM adopted by ANSYS. The accuracy of the FEM is assessed by comparison with the experimental results, which are to be in good agreement. The load-deflection curves from the finite element analysis agree well with the experimental results.

\section{LITERATURE REVIEW}

Some of the research work carried out on comparative study between experimental and analytical work in FRP strengthening describe below,

Amer Ibrahim [1] performed Numerical analysis on RC beams by ANSYS finite element program and results show that the general behavior of the finite element models represented by the load-deflection curves at mid span show good agreement with the test data. They also conclude that the load carrying capacity of the Flexure strengthening beam predicted by the finite element analysis is higher than that of the control beam.

Saifullah [2] performed destructive test on simply supported beam in laboratory and load-deflection data of that under RC beam. They compared both the computer modeling and experimental data and found that computer based modeling is can be an excellent alternative of destructive laboratory test with an acceptable variation of results.

Jayajothi [8] carried out the nonlinear Finite Element Analysis of Reinforced Concrete (RC) beams strengthened in flexure and shear by Fibre Reinforced Polymer (FRP) laminates and they found that the ultimate load carrying capacity of all the strengthened beams is higher when compared to the control beams and general behaviors of the FE models show good agreement with observations and data from the experimental tests.

Patil [9] described analysis of deep beams subjected to two point loading with different span to depth ratios using Non- 
linear FEM. They found that the smaller the span/depth ratio, the more pronounced was the deviation of strain pattern at midsection of the beam. As the depth of the beam increases the variation in strength, flexural steel and deflection were found to be more experimentally than the non-linear finite element analysis.

Uma [12] performed the flexural response of Reinforced Geopolymer Concrete (RGPC) beam. They compered the results from both ANSYS modeling and experimental data and found that the deflection obtained was found to be low due to meshing of element in the modeling. They also concluded that comparative result gives $20 \%$ difference for experimental and ANSYS 12.0.

\section{EXPERIMENTAL INVESTIGATION}

\subsection{Materials}

\subsubsection{Cement}

Portland Pozzolana cement conforming to IS 1489 (Part 1): 1991 was used obtained from ultratech cement. The physical properties of cement such as Initial and Final setting time are 170 and 270 minutes. Amount of Fly ash content in the cement is $28 \%$.

\subsubsection{Fine Aggregate}

Locally available river sand was used as fine aggregate as per IS 383: 1970 and their properties are given below.

Table -1: Physical Properties of Fine Aggregates

\begin{tabular}{|l|l|}
\hline Properties & Results of Natural Sand \\
\hline Bulk Density $\left(\mathrm{kg} / \mathrm{m}^{3}\right)$ & 1.23 \\
\hline Specific Gravity & 2.56 \\
\hline Fineness Modulus & 3.20 \\
\hline Water Absorption $(\%)$ & 1.4 \\
\hline
\end{tabular}

\subsubsection{Coarse Aggregate}

Crushed angular aggregate with maximum grain size of $20 \mathrm{~mm}$ and used as coarse aggregate as per IS 383: 1970. Their properties are bulk density $1.34 \mathrm{~kg} / \mathrm{m}^{3}$, specific gravity and fineness modulus was found to be 2.74 and 4.5 , respectively.

\subsubsection{Water}

Fresh portable water, which is free from acid and organic substance, was used for mixing the concrete.

\subsection{Mix Proportions and Mix Details}

Concrete mix design in this investigation was designed as per IS 10262: 2009 for M-25 grade concrete.
Table -2: Mix design proportions

\begin{tabular}{|l|l|l|l|l|}
\hline $\begin{array}{l}\text { Volume of } \\
\text { Concrete }\end{array}$ & Cement & Water & $\begin{array}{l}\text { Fine } \\
\text { Aggregate }\end{array}$ & $\begin{array}{l}\text { Course } \\
\text { Aggregate }\end{array}$ \\
\hline $\begin{array}{l}\text { By weight } \\
(\mathrm{kg} / \mathrm{m} 3)\end{array}$ & 394.32 & 197.16 & 669.53 & 1121.8 \\
\hline By volume & 1.00 & 0.50 & 1.70 & 2.85 \\
\hline
\end{tabular}

\subsection{Test}

\subsubsection{Flexure Strength}

The flexure strength of the concrete was determined according to Indian Standard 516:1959.

\subsection{Test Set Up}

The beams were modelled as volumes. The model is $2000 \mathrm{~mm}$ long, with a cross-section of $230 \mathrm{~mm} \times 300 \mathrm{~mm}$. The reinforcement at the bottom of beam is $2-12 \mathrm{~mm}$ dia and the reinforcement at top of beam is $2-10 \mathrm{~mm}$ dia, $8 \mathrm{~mm}$ dia stirrups (a) $250 \mathrm{~mm} \mathrm{c/c}$ as shown in Figure 1 and loading and support condition for both beam as shown in figure 2 .

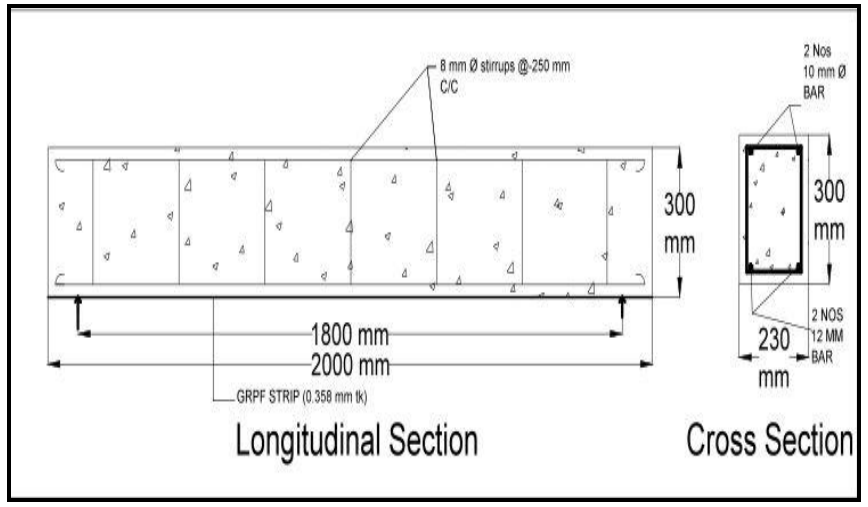

Fig -1: Typical details of test beam

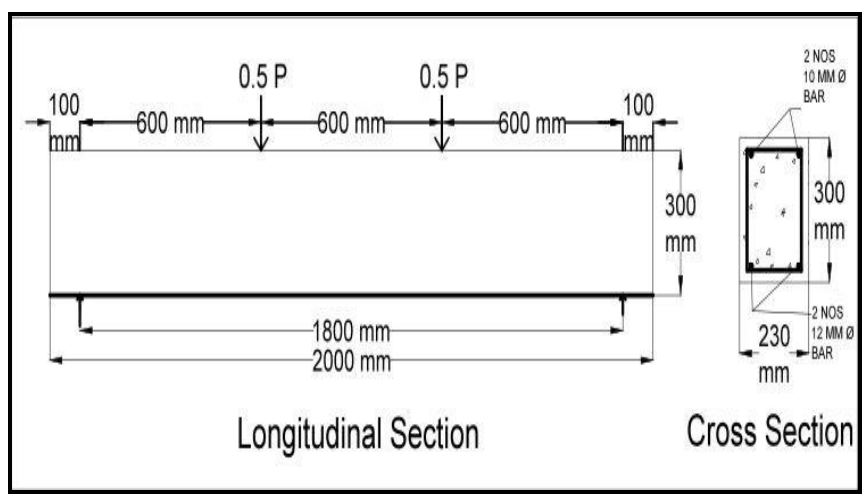

Fig -2: Details of Loading \& Supports Condition 
Tests were carried out at room temperature in our concrete laboratory. The testing arrangement was shown in figure 3 . Two point loads were applied on Control Beam (CB) and Bottom Single Strip Beam (BSS) of span $2 \mathrm{~m}$ through hydraulic jack of capacity $1000 \mathrm{KN}$. The beams were suitably instrumented for measuring of middle span deflection with Dial Gauge.

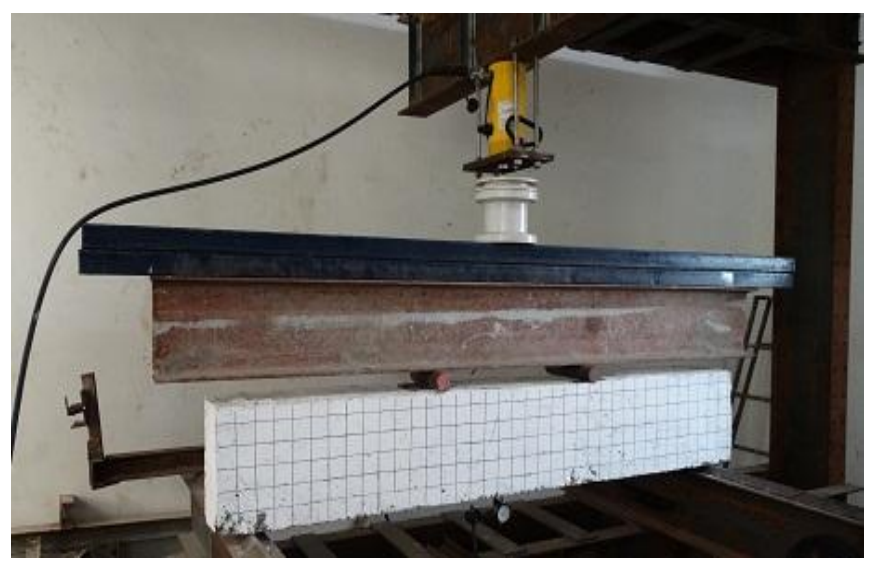

Fig -3: Experimental set up

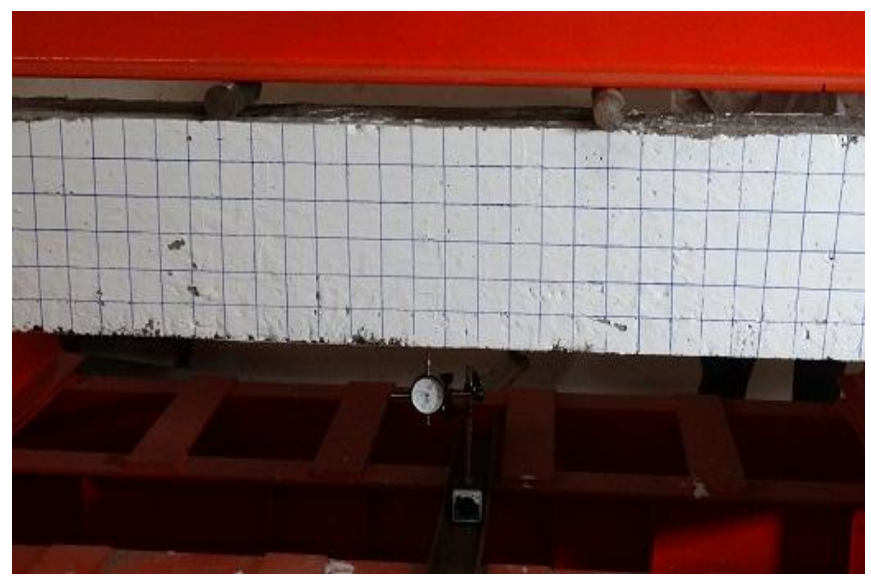

Fig -4: Arrangement of Dial Gauge at mid span

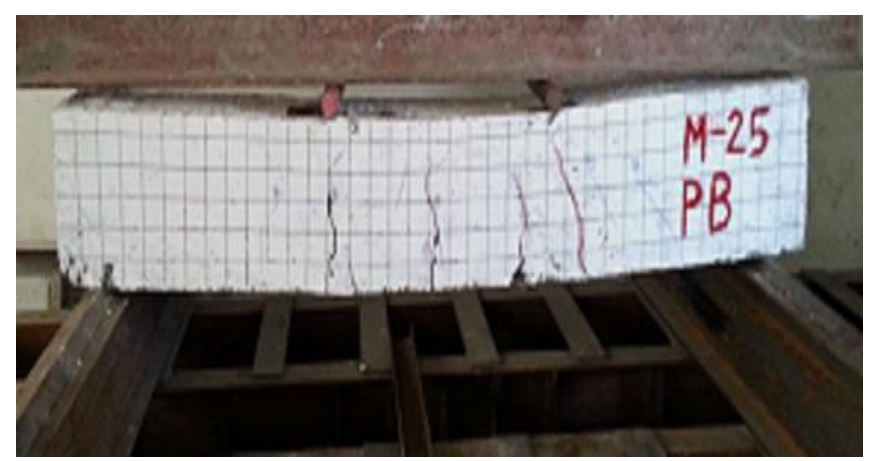

Fig -5: Crack pattern in Control Beam

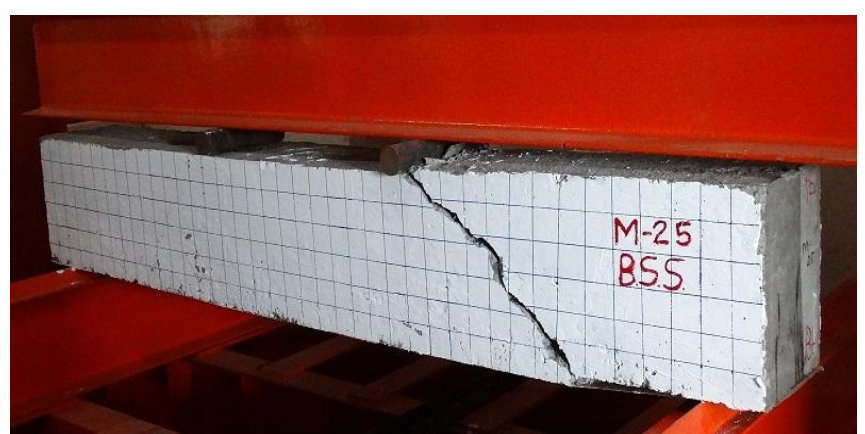

Fig -6: Crack pattern in Bottom Single Strip Beam

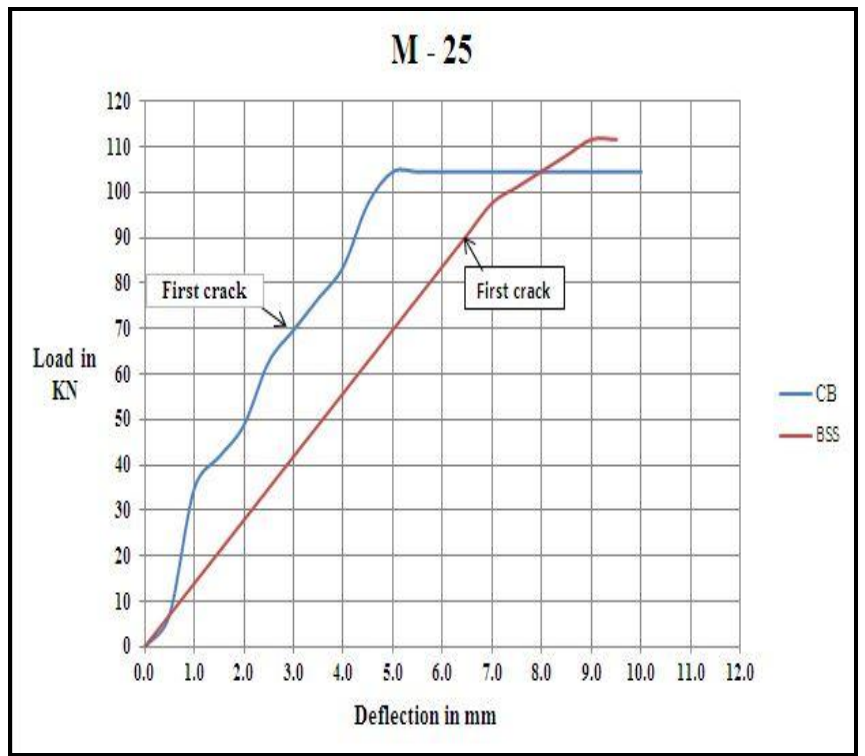

Fig -7: Load vs Deflection for the Test Beams

Comparisons between results of the design load and experimental load which is shown in table 3

Table -3: Result (As per ACI 440.2R-08)

\begin{tabular}{|l|l|l|l|}
\hline Grade & Designation & $\begin{array}{l}\text { Design } \\
\text { (Load in KN) }\end{array}$ & $\begin{array}{l}\text { Experimental } \\
\text { (Load in KN) }\end{array}$ \\
\hline \multirow{2}{*}{$\mathrm{M}-25$} & $\mathrm{CB}$ & 52 & 70 \\
\cline { 2 - 4 } & BSS & 80 & 90.74 \\
\hline
\end{tabular}

\section{ANALYTICAL INVESTIGATION}

In this paper, two beams were modelled and analysed using ANSYS software. In two beams, one beam was control beam and one beam was FRP Strengthened beam in bottom single strip. The control beam (CB) and Bottom Single Strip beam (BSS) is of size $2000 \times 230 \times 300 \mathrm{~mm}$. Element was used for analysis purpose which is shown in table 4 . 
Table -4: Element types for beam

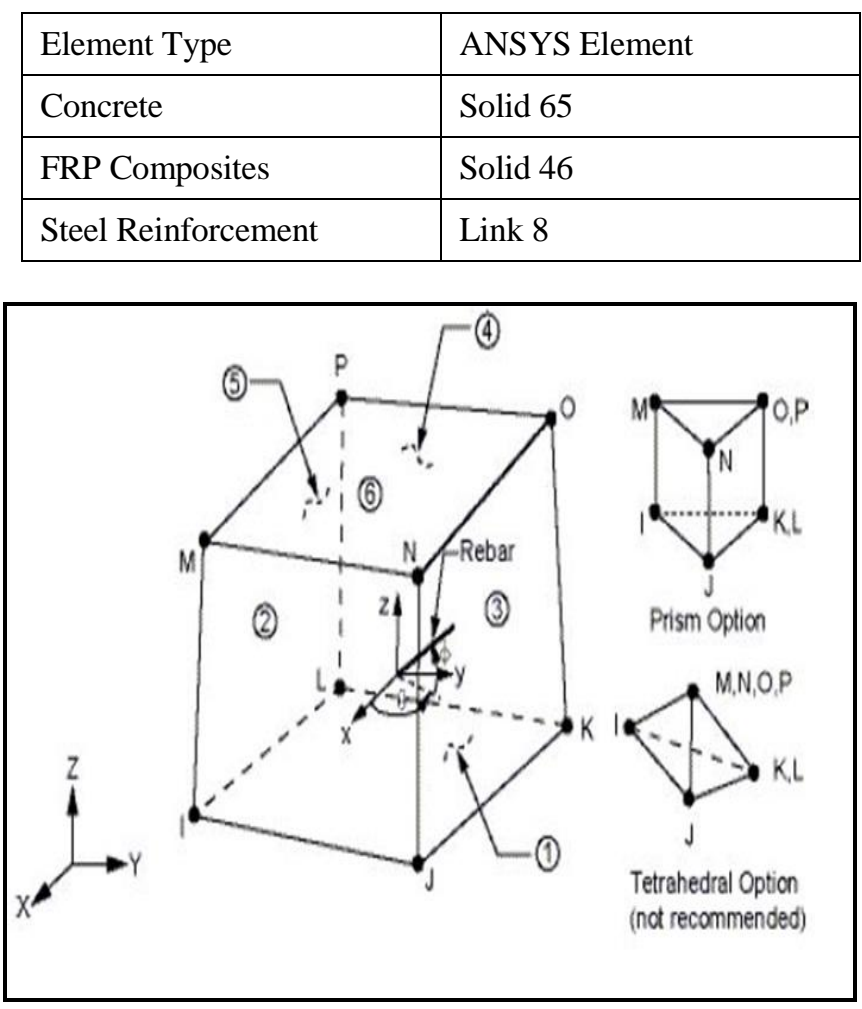

Fig -8: Solid 65 Element (ANSYS)

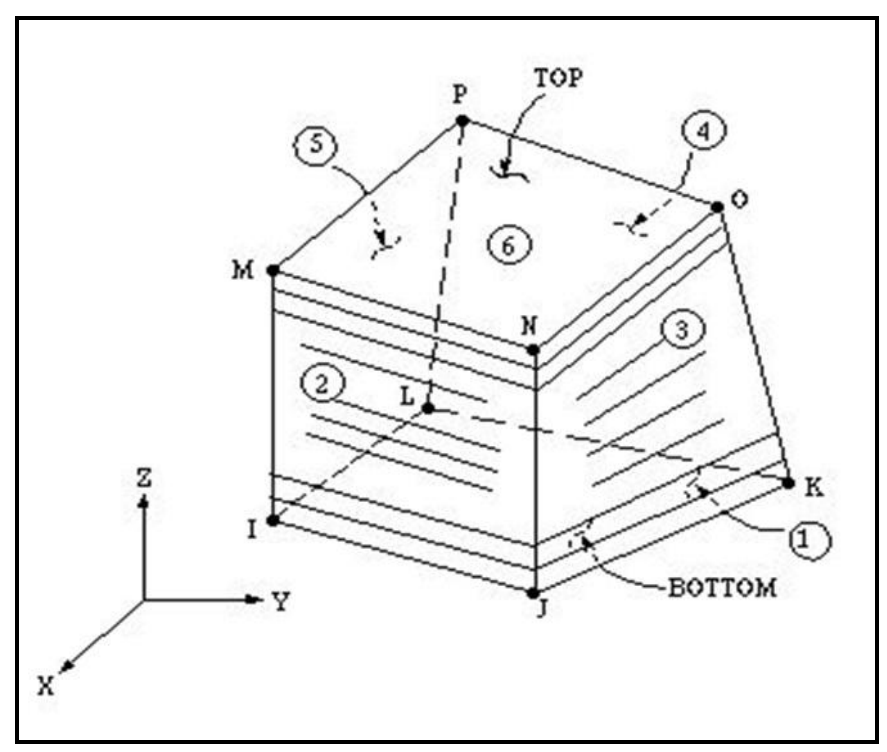

Fig -9: Solid 46 Element (ANSYS)

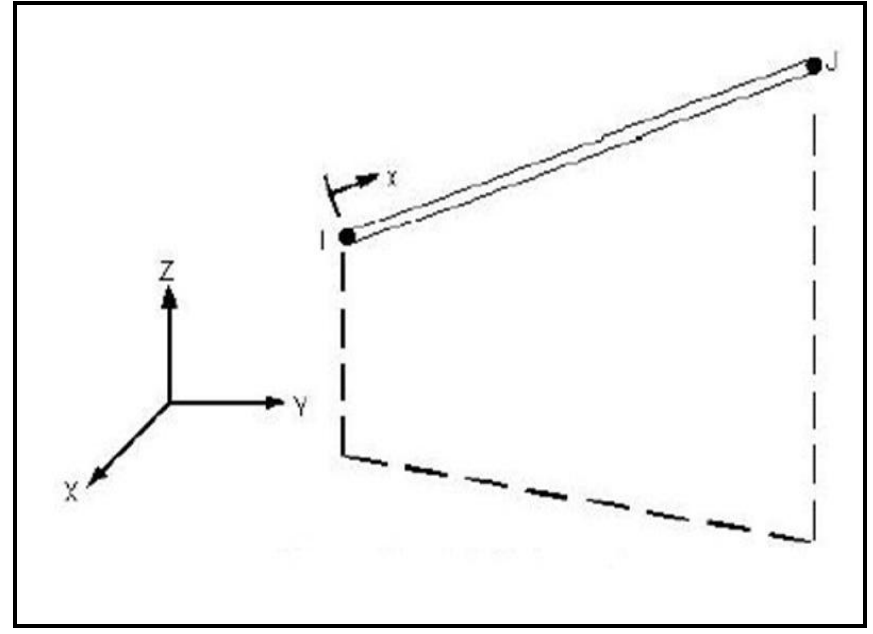

Fig -10: Link 8 Element (ANSYS)

Table -5: Real constant for beam model

\begin{tabular}{|c|c|c|c|c|c|}
\hline $\begin{array}{l}\text { Set } \\
\text { No }\end{array}$ & $\begin{array}{l}\text { Element } \\
\text { Type }\end{array}$ & \multicolumn{4}{|l|}{ Constants } \\
\hline \multirow{6}{*}{1} & \multirow{6}{*}{ Solid 65} & \multirow{2}{*}{ Properties } & \multicolumn{3}{|c|}{ Real Constants } \\
\hline & & & $\begin{array}{l}\text { Rebar } \\
1\end{array}$ & $\begin{array}{l}\text { Rebar } \\
2\end{array}$ & $\begin{array}{l}\text { Rebar } \\
3\end{array}$ \\
\hline & & $\begin{array}{l}\text { Material } \\
\text { Number }\end{array}$ & 0 & 0 & 0 \\
\hline & & $\begin{array}{l}\text { Volume } \\
\text { Ratio }\end{array}$ & 0 & 0 & 0 \\
\hline & & $\begin{array}{l}\text { Orientation } \\
\text { Angle }\end{array}$ & 0 & 0 & 0 \\
\hline & & $\begin{array}{l}\text { Orientation } \\
\text { Angle }\end{array}$ & 0 & 0 & 0 \\
\hline \multirow[t]{2}{*}{2} & Link 8 & $\begin{array}{l}\mathrm{C} / \mathrm{s} \\
(\mathrm{mm} 2)\end{array}$ & 113.09 & & \\
\hline & & Initial Strain & 0 & & \\
\hline \multirow[t]{2}{*}{3} & Link 8 & $\begin{array}{l}\mathrm{C} / \mathrm{s} \\
(\mathrm{mm} 2)\end{array}$ & 78.540 & & \\
\hline & & Initial Strain & 0 & & \\
\hline \multirow[t]{2}{*}{4} & Link8 & $\begin{array}{l}\mathrm{C} / \mathrm{s} \\
(\mathrm{mm} 2)\end{array}$ & 50.265 & & \\
\hline & & Initial Strain & 0 & & \\
\hline
\end{tabular}


Table -6: Material Properties for beam mode

\begin{tabular}{|c|c|c|c|c|}
\hline $\begin{array}{l}\text { Material } \\
\text { Model } \\
\text { Number }\end{array}$ & $\begin{array}{l}\text { Element } \\
\text { Type }\end{array}$ & \multicolumn{3}{|c|}{ Material Properties } \\
\hline \multirow{15}{*}{1} & \multirow{15}{*}{ Solid 65} & \multicolumn{3}{|c|}{ Linear Isotropic } \\
\hline & & EX & 25000 & $\mathrm{~N} / \mathrm{mm} 2$ \\
\hline & & PRXY & 0.2 & \\
\hline & & \multicolumn{3}{|c|}{ Multilinear Isotropics } \\
\hline & & Point & $\begin{array}{l}\text { Strain } \\
(\mathrm{mm} / \mathrm{mm})\end{array}$ & $\begin{array}{l}\text { Stress } \\
(\mathrm{N} / \mathrm{mm} 2)\end{array}$ \\
\hline & & 1 & 0.0003 & 7.5 \\
\hline & & 2 & 0.00054 & 12.68 \\
\hline & & 3 & 0.00124 & 22.39 \\
\hline & & 4 & 0.00184 & 24.91 \\
\hline & & 5 & 0.00237 & 25 \\
\hline & & \multicolumn{3}{|l|}{ Concrete } \\
\hline & & \multicolumn{2}{|c|}{ Open Shear Coeff. } & 0.3 \\
\hline & & \multicolumn{2}{|c|}{ Closed Shear Coeff. } & 1 \\
\hline & & \multicolumn{2}{|c|}{ Uniaxial Cracking Stress } & 3.58 \\
\hline & & \multicolumn{2}{|c|}{ Uniaxial Crushing Stress } & -1 \\
\hline \multirow{3}{*}{2} & \multirow{3}{*}{ Solid 46} & \multicolumn{3}{|c|}{ Linear Isotropic } \\
\hline & & EX & 76000 & $\mathrm{~N} / \mathrm{mm} 2$ \\
\hline & & PRXY & 0.28 & \\
\hline \multirow{6}{*}{3} & \multirow{6}{*}{ Link 8} & \multicolumn{3}{|c|}{ Linear Isotropic } \\
\hline & & EX & 200000 & $\mathrm{~N} / \mathrm{mm} 2$ \\
\hline & & PRXY & 0.3 & \\
\hline & & \multicolumn{3}{|c|}{ Bilinear Isotropic } \\
\hline & & $\begin{array}{l}\text { Yield } \\
\text { Stress }\end{array}$ & 415 & $\mathrm{~N} / \mathrm{mm} 2$ \\
\hline & & $\begin{array}{l}\text { Tangent } \\
\text { Modulus of } \\
\text { elasticity }\end{array}$ & 20 & $\mathrm{~N} / \mathrm{mm} 2$ \\
\hline
\end{tabular}

A finite element analysis requires meshing of the model. In other words, the model is divided into a number of small elements. The bond strength between the concrete and steel reinforcement should be considered. To provide the perfect bond, the link element for the steel reinforcing was connected between nodes of each adjacent concrete solid element, so the two materials shared the same nodes. The same approach was adopted for FRP composites. Meshing, Load and boundary conditions of both CB and BSS beam are shown in Fig 11 and Fig 12 respectively

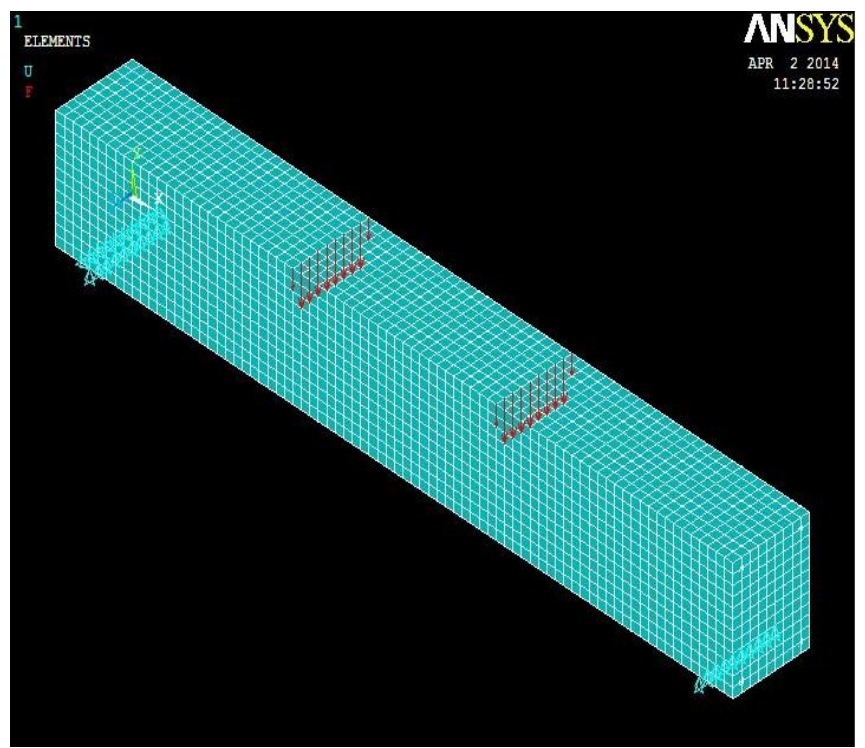

Fig -11: Meshing, Load and Boundary Condition for Control Beam

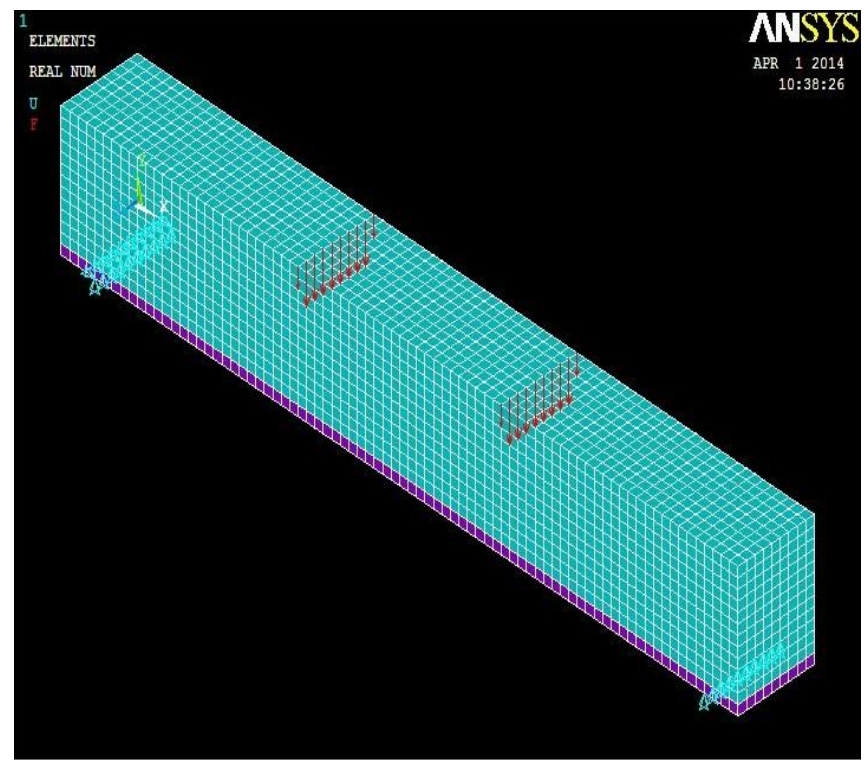

Fig -12: Meshing, Load and Boundary Condition for Bottom Single Strip Beam

The Sol'n Controls command dictates the use of a linear or nonlinear solution for the finite element model. The tolerance value of 0.001 is used for both force and displacement during the nonlinear solution for convergence. A small criterion must be used to capture correct response. This criteria was used for the remainder of the analysis. 


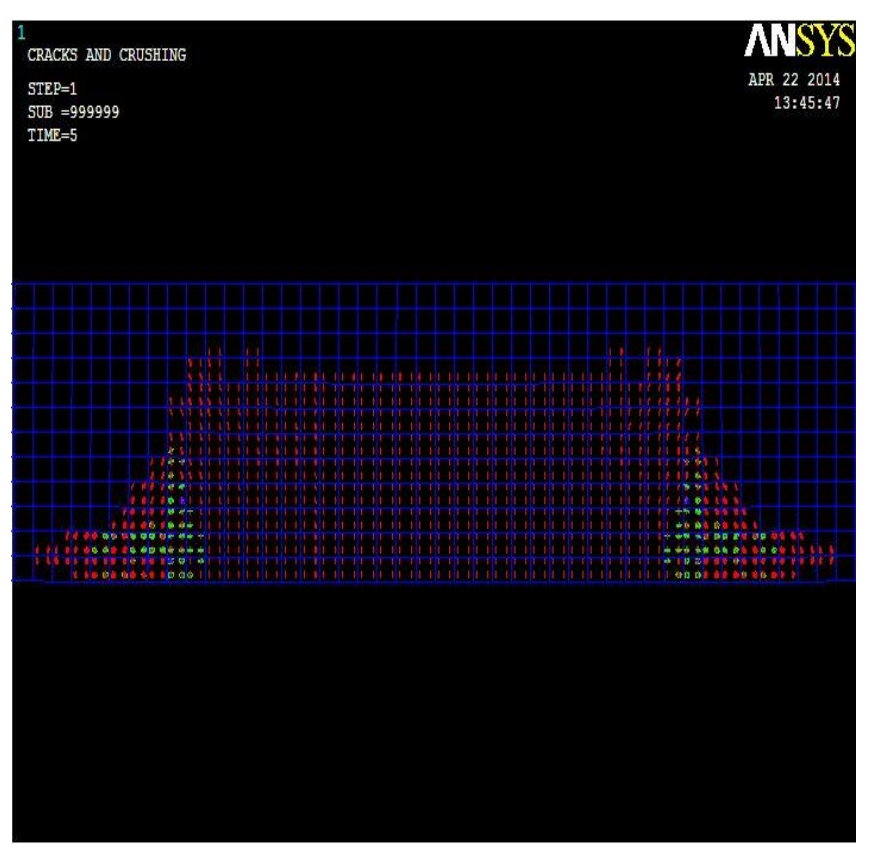

Fig -13: Cracking of the Control Beam

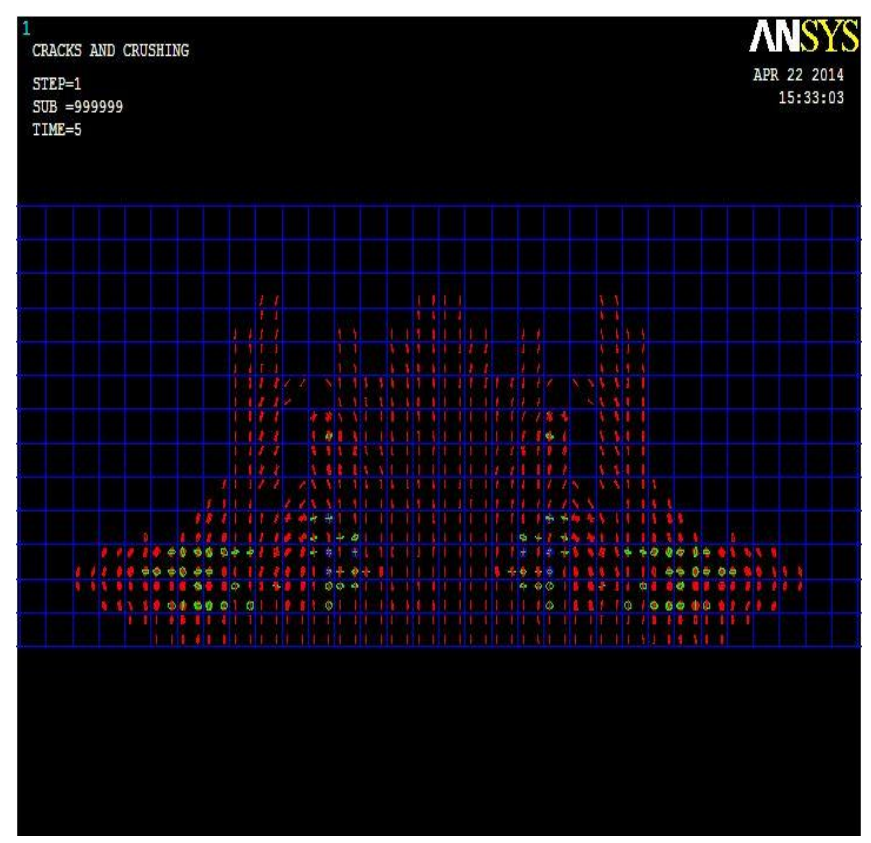

Fig -14: Cracking of the Bottom Single Strip Beam

\section{RESULTS AND DISCUSSIONS}

\subsection{Load Deflection Curves:}

Load-deflection curve for all two beams are shown in Figure 15 and Figure 16 respectively.

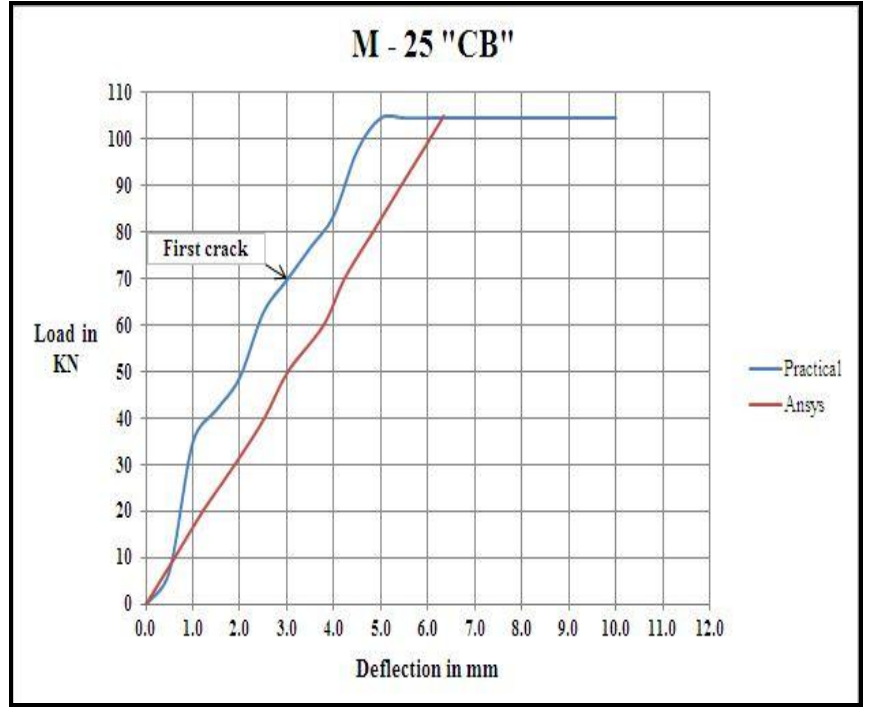

Fig -15: Load vs Deflection curve for Control Beam

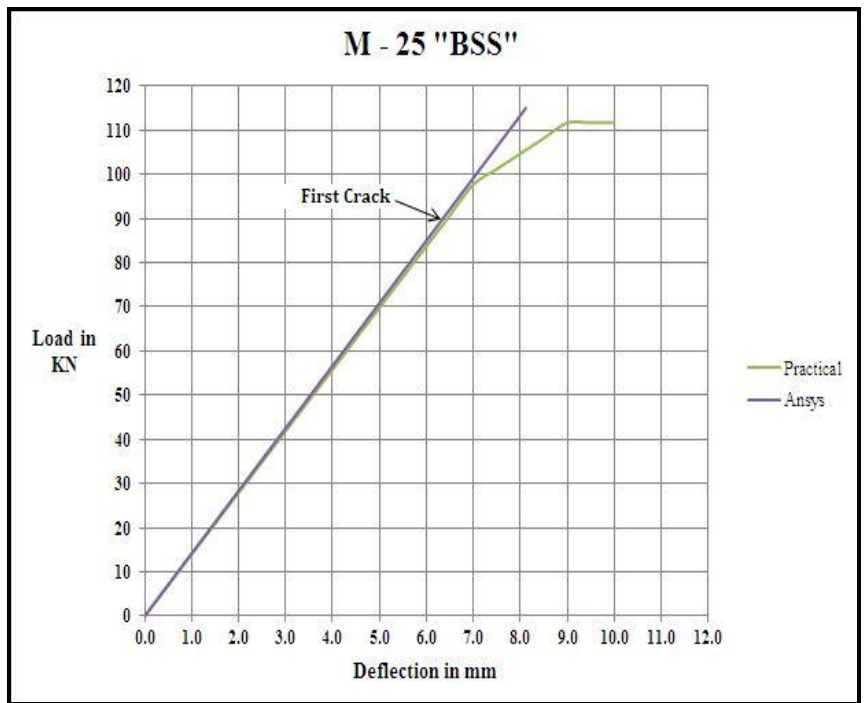

Fig -16: Load vs Deflection curve for Bottom Single Strip Beam

Table -7: Comparison of Ultimate loads for CB and BSS

\begin{tabular}{|c|c|c|c|c|c|}
\hline \multirow[t]{2}{*}{$\begin{array}{l}\text { Sr } \\
\text { No. }\end{array}$} & \multirow[t]{2}{*}{$\begin{array}{l}\text { Beam } \\
\text { Id }\end{array}$} & \multicolumn{2}{|c|}{ Ultimate Load in KN } & \multicolumn{2}{|c|}{$\begin{array}{l}\text { Percentage increase in } \\
\text { Flexure Capacity }\end{array}$} \\
\hline & & 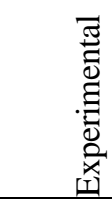 & 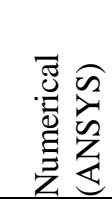 & 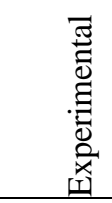 & 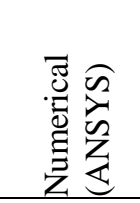 \\
\hline 1 & $\mathrm{CB}$ & 104.55 & 105 & - & - \\
\hline 2 & BSS & 111.68 & 115 & 6.82 & 9.52 \\
\hline
\end{tabular}


The experimental and numerical (ANSYS) ultimate loads are compared for both $\mathrm{CB}$ and BSS. It reveals that percentage increase in flexural capacity has been increased up to $6.82 \%$ in Experimental and $9.52 \%$ in Numerical (ANSYS) results.

\section{CONCLUSIONS}

Based on the experimental and analytical results and observations, it could be concluded that the ultimate load carrying capacity of the strengthened beam is higher when compared to the control beam. As per our design, beam has failed in flexure region under the application of two point load in Control Beam. The experimental failure load is $34 \%$ higher than the design load in case of Control beam and $13.42 \%$ in case of Bottom single strip beam. And also the type of failure changed from flexural failure to shear failure due to application of bottom single strip. The final loads from the finite element analysis are higher than the ultimate loads from the experimental results. Load vs. Deflection behavior is almost similar experimentally \& analytically in case of CB 25 \& BSS25.

\section{REFERENCES}

[1]. ACI 440.2R-08, Guild for the Design and Construction of Externally Bonded FRP Systems for Strengthening Concrete Structures, American Concrete Institute, U.S.A.

[2]. Amer M. Ibrahim, Wissam D. Salman, (December 2009). Finite element analysis of reinforced concrete beams strengthened with CFRP in flexural, Diyala Journal of Engineering Sciences, ISSN 1999-8716, Vol. 02 ,pages: 88-104. [3]. I.Saifullah, M.Nasir-uz-zaman, S.M.K. Uddin, M.A. Hossain, M.H. Rashid, (Feb. 2011). Experimental and analytical investigation of flexural behaviour of reinforced concrete beam, International Journal of Engineering \& Technology IJET IJENS Vol: 11 No: 01, Pages: 146-153.

[4]. K. L. Muthuramu, A. Chandran, S. Govindarajan, S. Karunanidhi, (August 2010). Strengthening of Reinforced Concrete Elements Using Glass Fiber, 35th conference on Our World in Concrete \& Structures, Article Id: 100035040, 25 - 27. [5]. Kaushal Parikh, C. D. Modhera, (2012). Application of GFRP on preloaded retrofitted beam for enhancement in flexural strength, International Journal of Civil and Structural Engineering, ISSN: 0976 - 4399, Volume 2, No 4.

[6]. N. Pannirselvam, P.N. Raghunath and K. Suguna, (2008). Strength Modeling of Reinforced Concrete Beam with Externally Bonded Fiber Reinforcement Polymer Reinforcement, American J. of Engineering and Applied Sciences 1 (3): 192-199, ISSN 1941-7020 C Science Publications.

[7]. P. Jayajothi, R. Kumutha and K. Vijai, (Feb.2013). Finite element analysis of FRP strengthened rc beams using ansys, Asian Journal of Civil Engineering (BHRC), Vol. 14, No. 4, Pages 631-642.

[8]. Prof. S. S. Patil, A. N. Shaikh, Prof. Dr. B. R. Niranjan, (Jan-Feb. 2013). Experimental and analytical study on reinforced concrete deep beam, International Journal of Modern
Engineering Research, ISSN: 2249-6645, Vol.3, Issue.1, pages: 45-52.

[9]. R. Balamuralikrishnan, C. Antony Jeyasehar, (2009). Flexural Behavior of RC Beams Strengthened with Carbon Fiber Reinforced Polymer (CFRP) Fabrics, The Open Civil Engineering Journal, Volume 3.

[10]. R. S. Ravichandran, K. Suguna, P.N. Raghunath, (January 2012). Flexural Behaviour of Composite High Strength Concrete - Fiber Reinforced Polymer Beams, IJCSET, ISSN: 2231 - 0711, Volume-2, Issue-1.

[11]. Uma.K. Anuradha.R., Venkatasubramani.R, (2012). Experimental investigation and analytical modeling of reinforced geopolymer concrete beam, International Journal of Civil And Structural Engineering, ISSN 0976 - 4399, Volume 2, Pages: $817-827$, No 3 .

\section{BIOGRAPHIES}

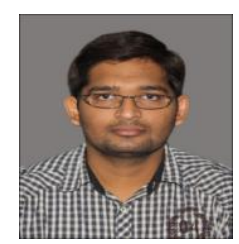

Shaishav Ratilal Viradiya was born in 1987. $\mathrm{He}$ receives his Bachelor of Engineering degree in Civil Engineering from the BVM College, V.V.Nagar in 2012. At present he is Final year student of Master's degree in Structural engineering from Marwadi Education Foundation Group of Institutions, Gujarat Technological University

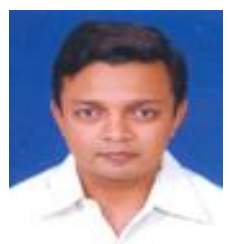

Prof. Tarak P. Vora an academician by hard with a teaching experience of twelve years $\mathrm{He}$ is pursuing his $\mathrm{PhD}$ in Civil Engineering from Gujarat Technological University. His area of interest is experimental stress analysis, FE Analysis, Structural Dynamics etc. 